\title{
Specificity of ultrastructural changes of small intestinal epithelium in early childhood
}

\author{
M. ARAYA and J. A. WALKER-SMITH \\ From the Departments of Medicine, Royal Alexandra Hospital for Children and University of Sydney \\ and the Royal Hospital of St. Bartholomew, London
}

\begin{abstract}
Araya, M., and Walker-Smith, J. A. (1975). Archives of Disease in Childhood, 50, 844. Specificity of ultrastructural changes of small intestinal epithelium in early childhood. Electron microscopical features of the small intestinal mucosa in 30 consecutive biopsies from 14 newly diagnosed coeliac patients, and 16 patients with chronic intermittent diarrhoea due to different causes, were studied. An attempt to define specific changes in each condition was made.

An abnormal brush border, increased number of free ribosomes, rich rough endoplasmic reticulum, poorly developed smooth endoplasmic reticulum, large Golgi complexes, and thickened basal lamina were the most frequent findings in the coeliac biopsies. These changes suggest abnormal cellular metabolism, but as they were also observed in children with a variety of clinical conditions, they could not be specifically related to coeliac disease. These observations suggest that in small children different causes leading to different degrees of abnormal small intestinal mucosa, as observed with the light microscope, produce nonspecific changes of the cellular ultrastructure, which cannot be related to the degree of abnormality observed at the light microscope level.
\end{abstract}

The ultrastructure of the small intestinal epithelium has now been studied by a number of observers, during normal and pathological conditions, in the search for typical features to characterize the different diseases (Hartman et al., 1959; Palay and Karlin, 1959; Rubin et al., 1960; Brown, 1962; Trier, 1963). Coeliac disease is one of the entities most extensively studied and abnormalities of the brush border, lysosomes, nuclei, and thickening of the basal membrane have been considered as typical of this disease (Hartman et al., 1960; Shiner and Birbeck, 1961; Curran and Creamer, 1963; Trier and Rubin, 1965; Shiner, 1967; Biempica, Toccalino, and O'Donnell, 1968). The thickening of the basal lamina has been shown to be one of the first and more constant changes to occur after challenging a patient in remission with gluten (Biempica et al., 1968; Shmerling and Shiner, 1969; Shiner and Shmerling, 1970). However, these types of changes have also been reported in recent years in other conditions, such as cow's milk protein intolerance (Kuitunen et al., 1973), parasitic infestation (Ament, 1972), postgastroenteritis syndrome (Ament, 1972), and soya bean intolerance (Ament

Received 24 March 1975. and Rubin, 1972). There is little information about the specificity of the ultrastructural changes of the small intestine in young children when mucosal damage occurs due to coeliac disease and when it is secondary to causes other than coeliac disease.

The present study was planned to review the ultrastructure of the small intestinal mucosa of 30 consecutive small intestinal biopsies taken from children at the Royal Alexandra Hospital for Children. These 30 biopsies included children with probable coeliac disease, children who had nonspecific mucosal damage (partial villous atrophy), and children with normal small intestinal mucosa. We compare and contrast the ultrastructural appearances found in these types of children, with special emphasis on those signs thought to be 'typical' of coeliac disease.

\section{Material and methods}

Patients. 30 consecutive children, 18 males and 12 females, between the ages of 8 months and 12 years, were studied, details of whom are set out in Table I.

Fourteen children were considered to have probable coeliac disease, as the following criteria were fulfilled. (i) A suggestive clinical history. (ii) A flat or almost flat, convoluted pattern with visible crypt openings on 
TABLE I

Jejunal biopsy appearances in 14 coeliac patients, and in 16 children with other forms of diarrhoea

\begin{tabular}{|c|c|c|c|c|}
\hline Case no. & $\begin{array}{c}\text { Age } \\
(\mathrm{yr})(\mathrm{m})\end{array}$ & Diagnosis & Dissecting microscopy & Light microscopy \\
\hline 1 & 8 & Coeliac disease & Flat & Subtotal villous atrophy \\
\hline 2 & 14 & ” & 川 & " \\
\hline $\begin{array}{l}3 \\
4\end{array}$ & 15 & " & " & " \\
\hline 5 & $\begin{array}{ll}1 & 6 \\
1 & 6\end{array}$ & $"$ & " & " \\
\hline 6 & 16 & ” & 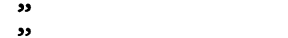 & ” \\
\hline $\begin{array}{l}7 \\
8\end{array}$ & 22 & $"$ & C" & Severe nartial villous \\
\hline & & & visible crypt openings & $\begin{array}{l}\text { atrophy } \\
\text { atrols }\end{array}$ \\
\hline 9 & 42 & " & Flat & $\Rightarrow$ \\
\hline $\begin{array}{l}10 \\
11\end{array}$ & $\begin{array}{l}48 \\
5\end{array}$ & " & $\begin{array}{l}\text { Flat } \\
\text { Convoluted pattern with }\end{array}$ & " \\
\hline 12 & 6 & " & $\begin{array}{l}\text { visible crypt openings } \\
\text { Convoluted pattern with }\end{array}$ & 》 \\
\hline $\begin{array}{l}13 \\
14\end{array}$ & 106 & ”, & $\begin{array}{l}\text { Flat } \\
\text { Flat }\end{array}$ & $\begin{array}{l}\text { Subtotal villous atrophy } \\
\text { Severe partial villous }\end{array}$ \\
\hline 15 & 9 & $\begin{array}{l}\text { Failure to thrive, chronic } \\
\text { intermittent diarrhoes }\end{array}$ & Normal & Normal \\
\hline 16 & 9 & $\begin{array}{l}\text { Failure to thrive, chronic } \\
\text { intermittent diarrhoea }\end{array}$ & ” & Normal \\
\hline 17 & 1 & $\begin{array}{l}\text { Postgastroenteritis } \\
\text { syndrome }\end{array}$ & " & Mild partial villous \\
\hline 18 & 11 & Chronic intermittent & ” & Mild partial villous \\
\hline 19 & 2 & $\begin{array}{l}\text { Steatorrhoea of unknown } \\
\text { origin }\end{array}$ & " & Normal \\
\hline 20 & 23 & Giardiasis & " & Mild partial villous \\
\hline 21 & 23 & Postgastroentroenteritis & ” & Normal \\
\hline 22 & 26 & $\begin{array}{l}\text { Chronic intermittent } \\
\text { diarrhoea; ?irritable } \\
\text { colon syndrome }\end{array}$ & " & " \\
\hline $\begin{array}{l}23 \\
24\end{array}$ & $\begin{array}{l}29 \\
39\end{array}$ & $\begin{array}{l}\text { Cow's milk intolerance } \\
\text { Failure to thrive, chronic } \\
\text { intermittent diarrhoea }\end{array}$ & $"$ & " \\
\hline 25 & 4 & Chronic intermittent & " & ” \\
\hline 26 & 5 & $\begin{array}{l}\text { Normal child, sib of child } \\
\text { with vitamin } B_{12}\end{array}$ & " & " \\
\hline 27 & 53 & $\begin{array}{l}\text { Failure to thrive, chronic } \\
\text { intermittent diarrhoea }\end{array}$ & " & " \\
\hline 28 & 8 & $\begin{array}{l}\text { Chronic intermittent } \\
\text { diarrhoea; mental } \\
\text { retardation }\end{array}$ & ” & " \\
\hline 29 & 11 & $\begin{array}{l}\text { Normal child, sib of child } \\
\text { with vitamin } B_{12} \\
\text { malabsorption }\end{array}$ & פ & " \\
\hline 30 & 12 & $\begin{array}{l}\text { Chronic intermittent } \\
\text { diarrhoea; ? irritable } \\
\text { colon syndrome }\end{array}$ & " & " \\
\hline
\end{tabular}

dissecting microscope examination of the small intestinal biopsy. (iii) Subtotal or severe partial villous atrophy with hypertrophic crypts and increased cellularity of the lamina propria on light microscope examination of the biopsy. (iv) Good clinical response to a gluten-free diet.

As this study was carried out prospectively, these children have not yet been challenged with gluten after a period of thriving on a gluten-free diet. Therefore, the diagnosis of coeliac disease still remains to be proven, but nonetheless is highly probable. For comparison they will hereafter be referred to as coeliacs.

Sixteen children were biopsied because they had chronic intermittent diarrhoea and failure to thrive. Two were sibs of a child with vitamin $B_{12}$ malabsoprtion. Dissecting microscope examination of all these biopsies was regarded as being within normal limits (i.e. tonguelike, leaf-like, and long thin ridge-like villi). Light microscopy was normal in 12 cases and showed a 
moderate degree of partial villous atrophy in four biopsies (Table I). In three (Cases 15, 22, and 30, Table I) an abnormal sociopsychological history was obtained and a motility disorder related to this was diagnosed (? irritable colon syndrome). In one child (Case 23) there was a history strongly suggestive of cow's milk intolerance. In 2 children (Cases 17 and 21) there was an antecedent history of acute vomiting and diarrhoea, and the diagnosis of postgastroenteritis syndrome was made. In the remaining cases there was no definite diagnosis made.

Biopsies. All biopsies were taken at the duodenojejunal junction with a paediatric Crosby biopsy capsule (Watson modification) and cut into two. One half was fixed in formalin for routine light microscope study. The other half was cut into two again and processed as follows.

The biopsy was fixed in freshly prepared (a) bicarbonate buffered $2 \% \mathrm{OsO}_{4}, \mathrm{pH} 7 \cdot 4$ for one hour, and/or (b) cacodylate buffered $2 \cdot 5 \%$ glutaraldehyde, $\mathrm{pH} 7 \cdot 4$ for one hour, and postosmicated in $2 \%$ buffered $\mathrm{OsO}_{4}$, $p \mathrm{H} \mathrm{7.4}$ for one hour. The biopsies were then treated with uranyl acetate (Watson, 1958), dehydrated in graded ethanols and propylene oxide, and afterwards embedded in Epon 812. Thick sections were obtained and stained with toluidine blue (Trump, Smuckler, and Benditt, 1961). A middle third villus area was selected in one block and a deep crypt area in the other block. Numerous thin silver sections were cut from these areas,

Morphological appearance of Golgi apparatus, free ribosomes and polysomes, rough endoplismi

\begin{tabular}{|c|c|c|c|c|}
\hline \multirow{2}{*}{ Case no. } & \multirow{2}{*}{ Golgi } & \multicolumn{2}{|c|}{ Polysomes and free ribosomes } & \multirow{2}{*}{$\begin{array}{c}\begin{array}{c}\text { Rọgh } \\
\text { ～ret }\end{array} \\
\text { Viless }\end{array}$} \\
\hline & & Villus & Crypt & \\
\hline $\begin{array}{l}1 \\
2\end{array}$ & $\begin{array}{l}\text { Prominent } \\
\text { Prominent }\end{array}$ & $\begin{array}{l}\text { Numerous } \\
\text { Few }\end{array}$ & $\begin{array}{l}\text { Very numerous } \\
\text { Numerous }\end{array}$ & $\begin{array}{l}\text { Normgl } \\
\text { Very } \bar{O} \\
\text { abindan }\end{array}$ \\
\hline $\begin{array}{l}3 \\
4\end{array}$ & $\begin{array}{l}\text { Prominent } \\
\text { Prominent } \\
+++\end{array}$ & $\begin{array}{l}\text { Very numerous } \\
\text { Few }\end{array}$ & $\begin{array}{l}\text { Very numerous } \\
\text { Very numerous }\end{array}$ & Poor \\
\hline $\begin{array}{l}5 \\
6\end{array}$ & $\begin{array}{l}\text { Prominent } \\
\text { Prominent } \\
+++\end{array}$ & $\begin{array}{l}\text { Numerous } \\
\text { Very numerous }\end{array}$ & $\begin{array}{l}\text { Very numerous } \\
\text { Very numerous }\end{array}$ & $\begin{array}{l}\text { Abundant } \\
\text { Normagi }\end{array}$ \\
\hline $\begin{array}{l}7 \\
8\end{array}$ & $\begin{array}{l}\text { Normal } \\
\text { Prominent } \\
+++\end{array}$ & $\begin{array}{l}\text { Normal amount } \\
\text { Very numerous }\end{array}$ & $\begin{array}{l}\text { Numerous } \\
\text { Very numerous }\end{array}$ & $\begin{array}{l}\text { Normis } \\
\text { Abuntant }\end{array}$ \\
\hline $\begin{array}{r}9 \\
10\end{array}$ & $\begin{array}{l}\text { Prominent } \\
\text { Prominent } \\
+++\end{array}$ & $\begin{array}{l}\text { Numerous } \\
\text { Very numerous }\end{array}$ & $\begin{array}{l}\text { Very numerous } \\
\text { Very numerous }\end{array}$ & 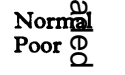 \\
\hline 11 & Normal & Very numerous & Numerous & Abungtant \\
\hline 12 & $\begin{array}{l}\text { Prominent } \\
+++\end{array}$ & Normal amount & Very numerous & 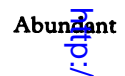 \\
\hline 13 & $\begin{array}{l}\text { Prominent } \\
+++\end{array}$ & Numerous & Very numerous & Abungfant \\
\hline $\begin{array}{l}14 \\
15 \\
16 \\
17 \\
18 \\
19\end{array}$ & $\begin{array}{l}\text { Prominent } \\
\text { Prominent } \\
\text { Normal } \\
\text { Normal } \\
\text { Prominent } \\
\text { Prominent }\end{array}$ & $\begin{array}{l}\text { Very numerous } \\
\text { Very numerous } \\
\text { Very numerous } \\
\text { Normal amount } \\
\text { Normal amount } \\
\text { Normal amount }\end{array}$ & $\begin{array}{l}\text { Very numerous } \\
\text { Very numerous } \\
\text { Very numerous } \\
\text { Numerous } \\
\text { Very numerous } \\
\text { Numerous }\end{array}$ & $\begin{array}{l}\text { Abundant } \\
\text { Abundant } \\
\text { Norngal } \\
\text { Abungant } \\
\text { Poor } \\
\text { Poor }\end{array}$ \\
\hline 20 & Prominent & Numerous & Numerous & Normal \\
\hline $\begin{array}{l}21 \\
22\end{array}$ & $\begin{array}{l}\text { Prominent } \\
\text { Prominent }\end{array}$ & $\begin{array}{l}\text { Normal amount } \\
\text { Normal amount }\end{array}$ & $\begin{array}{l}\text { Very numerous } \\
\text { Few }\end{array}$ & $\begin{array}{l}\text { Abuneant } \\
\text { Abundint }\end{array}$ \\
\hline 23 & $\begin{array}{l}\text { Prominent } \\
+++\end{array}$ & Normal amount & Numerous & Abundant \\
\hline 24 & $\begin{array}{l}\text { Prominent } \\
+++\end{array}$ & Normal amount & Very numerous & Abunfęnt \\
\hline $\begin{array}{l}25 \\
26 \\
27 \\
28 \\
29 \\
30\end{array}$ & $\begin{array}{l}\text { Prominent } \\
\text { Normal } \\
\text { Normal } \\
\text { Prominent } \\
\text { Prominent } \\
\text { Prominent } \\
+++\end{array}$ & $\begin{array}{l}\text { Very numerous } \\
\text { Very numerous } \\
\text { Few } \\
\text { Normal amount } \\
\text { Numerous } \\
\text { Numerous }\end{array}$ & $\begin{array}{l}\text { Very numerous } \\
\text { Very numerous } \\
\text { Numerous } \\
\text { Numerous } \\
\text { Very numerous } \\
\text { Very numerous }\end{array}$ & 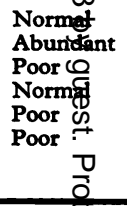 \\
\hline & & & & 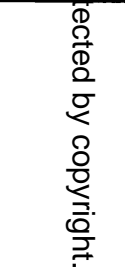 \\
\hline
\end{tabular}


stained with lead citrate (Reynolds, 1963) and studied with a Philips 200 electron microscope. The prints obtained were studied and coded by one of the authors (M.A.) so that they could be restudied and reclassified blindly by another observer.

\section{Results}

Clinical. Relevant clinical details of children studied are shown in Table I.

Electronmicroscopy (Table II). The brush border appeared completely disorganized with a poor or absent glycocalyx covering in all 14 coeliac cases (Fig. 1a). In one coeliac patient (Case 4), however, extensive patchy areas of normal brush border were found in villus and crypt areas (Fig. 1b). There was no gluten withdrawal before the biopsy. Normal brush border was the most common finding in the 'noncoeliac' group (Fig. 1c). In most of the 16 noncoeliac biopsies there were small patchy areas along the villi which showed shorter, looser, and sometimes branched microvilli. The glycocalyx was always normal and pinocytotic vesicles were frequent.

The terminal web was well developed in most cases and occasionally presented with disrupted

ticulum, smooth endoplasmic reticulum, and basal membrane in villus and crypt areas

\begin{tabular}{|c|c|c|c|c|}
\hline \multirow{2}{*}{$\frac{\operatorname{masmic}^{\text {lasmyt }}}{\text { Crypt }}$} & \multicolumn{2}{|c|}{$\begin{array}{l}\text { Smooth endoplasmic } \\
\text { reticulum }\end{array}$} & \multicolumn{2}{|c|}{ Basal membrane } \\
\hline & Villus & Crypt & Villus & Crypt \\
\hline $\begin{array}{l}\text { bundant } \\
\text { oor }\end{array}$ & $\begin{array}{l}\text { Poor } \\
\text { Poor-nil }\end{array}$ & $\begin{array}{l}\text { Poor } \\
\text { Poor }\end{array}$ & $\begin{array}{l}\text { Normal } \\
\text { Normal }\end{array}$ & $\begin{array}{l}\text { Normal } \\
\text { Normal }\end{array}$ \\
\hline $\begin{array}{l}\text { ich } \\
\text { bundant }\end{array}$ & $\begin{array}{l}\text { Poor-nil } \\
\text { Absent }\end{array}$ & $\begin{array}{l}\text { Poor } \\
\text { Poor }\end{array}$ & $\begin{array}{l}\text { Normal } \\
\text { Normal }\end{array}$ & $\begin{array}{l}\text { Normal } \\
\text { Normal }\end{array}$ \\
\hline $\begin{array}{l}\text { boundant } \\
\text { oor }\end{array}$ & $\begin{array}{l}\text { Poor } \\
\text { Poor }\end{array}$ & $\begin{array}{l}\text { Poor } \\
\text { Poor-nil }\end{array}$ & $\begin{array}{l}\text { Normal } \\
\text { Normal }\end{array}$ & $\begin{array}{l}\text { Normal } \\
\text { Thickened }\end{array}$ \\
\hline $\begin{array}{l}\text { Jormal } \\
\text { lbundant }\end{array}$ & $\begin{array}{l}\text { Poor } \\
\text { Poor }\end{array}$ & $\begin{array}{l}\text { Poor } \\
\text { Poor-nil }\end{array}$ & $\begin{array}{l}\text { Normal } \\
\text { Thickened }\end{array}$ & $\begin{array}{l}\text { Thickened } \\
\text { Normal }\end{array}$ \\
\hline $\begin{array}{l}\text { Ibundant } \\
\text { Ooor }\end{array}$ & $\begin{array}{l}\text { Poor } \\
\text { Poor }\end{array}$ & $\begin{array}{l}\text { Poor-nil } \\
\text { Poor-nil }\end{array}$ & $\begin{array}{l}\text { Normal } \\
\text { Normal }\end{array}$ & $\begin{array}{l}\text { Thickened } \\
\text { Normal }\end{array}$ \\
\hline Jormal & Poor & $\begin{array}{l}\text { Dilated } \\
\text { abnormal } \\
\text { vesicles }\end{array}$ & Normal & Normal \\
\hline 'oor & $\begin{array}{l}\text { Rich, } \\
\text { dilated, } \\
\text { vesicles }\end{array}$ & Poor & Thickened & Normal \\
\hline 'oor & Poor & Poor & Thickened & Normal \\
\hline $\begin{array}{l}\text { tbundant } \\
\text { tbundant } \\
\text { tbundant } \\
\text { tbundant } \\
\text { tbundant } \\
\text { Jormal }\end{array}$ & $\begin{array}{l}\text { Poor } \\
\text { Poor } \\
\text { Poor } \\
\text { Rich } \\
\text { Poor } \\
\text { Rich, } \\
\quad \text { dilated }\end{array}$ & $\begin{array}{l}\text { Poor } \\
\text { Poor } \\
\text { Poor-nil } \\
\text { Normal } \\
\text { Poor } \\
\text { Normal }\end{array}$ & $\begin{array}{l}\text { Normal } \\
\text { Thickened } \\
\text { Thickened } \\
\text { Thickened } \\
\text { Normal } \\
\text { Thickened }\end{array}$ & $\begin{array}{l}\text { Thickened } \\
\text { Normal } \\
\text { Normal } \\
\text { Normal } \\
\text { Normal } \\
\text { Thickened }\end{array}$ \\
\hline Abundant & $\begin{array}{l}\text { Rich, } \\
\text { dilated }\end{array}$ & $\begin{array}{l}\text { Rich, } \\
\text { dilated, }\end{array}$ & Normal & Normal \\
\hline $\begin{array}{l}\text { Abundant } \\
\text { tbundant }\end{array}$ & $\begin{array}{l}\text { Rich } \\
\text { Rich, } \\
\text { dilated }\end{array}$ & $\begin{array}{l}\text { Poor } \\
\text { Rich, } \\
\text { dilated }\end{array}$ & $\begin{array}{l}\text { Normal } \\
\text { Thickened }\end{array}$ & $\begin{array}{l}\text { Normal } \\
\text { Normal }\end{array}$ \\
\hline Abundant & $\begin{array}{l}\text { Rich, } \\
\text { dilated }\end{array}$ & $\begin{array}{l}\text { Rich, } \\
\text { dilated }\end{array}$ & Thickened & Normal \\
\hline ?oor & $\begin{array}{l}\text { Rich, } \\
\text { dilated }\end{array}$ & $\begin{array}{l}\text { Rich, } \\
\text { dilated }\end{array}$ & Normal & Normal \\
\hline $\begin{array}{l}\text { Poor } \\
\text { Normal } \\
\text { Normal } \\
\text { Normal } \\
\text { Normal } \\
\text { Normal }\end{array}$ & $\begin{array}{l}\text { Rich } \\
\text { Poor } \\
\text { Rich } \\
\text { Normal } \\
\text { Poor } \\
\text { Rich }\end{array}$ & $\begin{array}{l}\text { Poor } \\
\text { Poor } \\
\text { Normal } \\
\text { Poor } \\
\text { Poor } \\
\text { Normal }\end{array}$ & $\begin{array}{l}\text { Normal } \\
\text { Normal } \\
\text { Normal } \\
\text { Thickened } \\
\text { Normal } \\
\text { Thickened }\end{array}$ & $\begin{array}{l}\text { Normal } \\
\text { Normal } \\
\text { Thickened } \\
\text { Normal } \\
\text { Normal } \\
\text { Normal }\end{array}$ \\
\hline
\end{tabular}




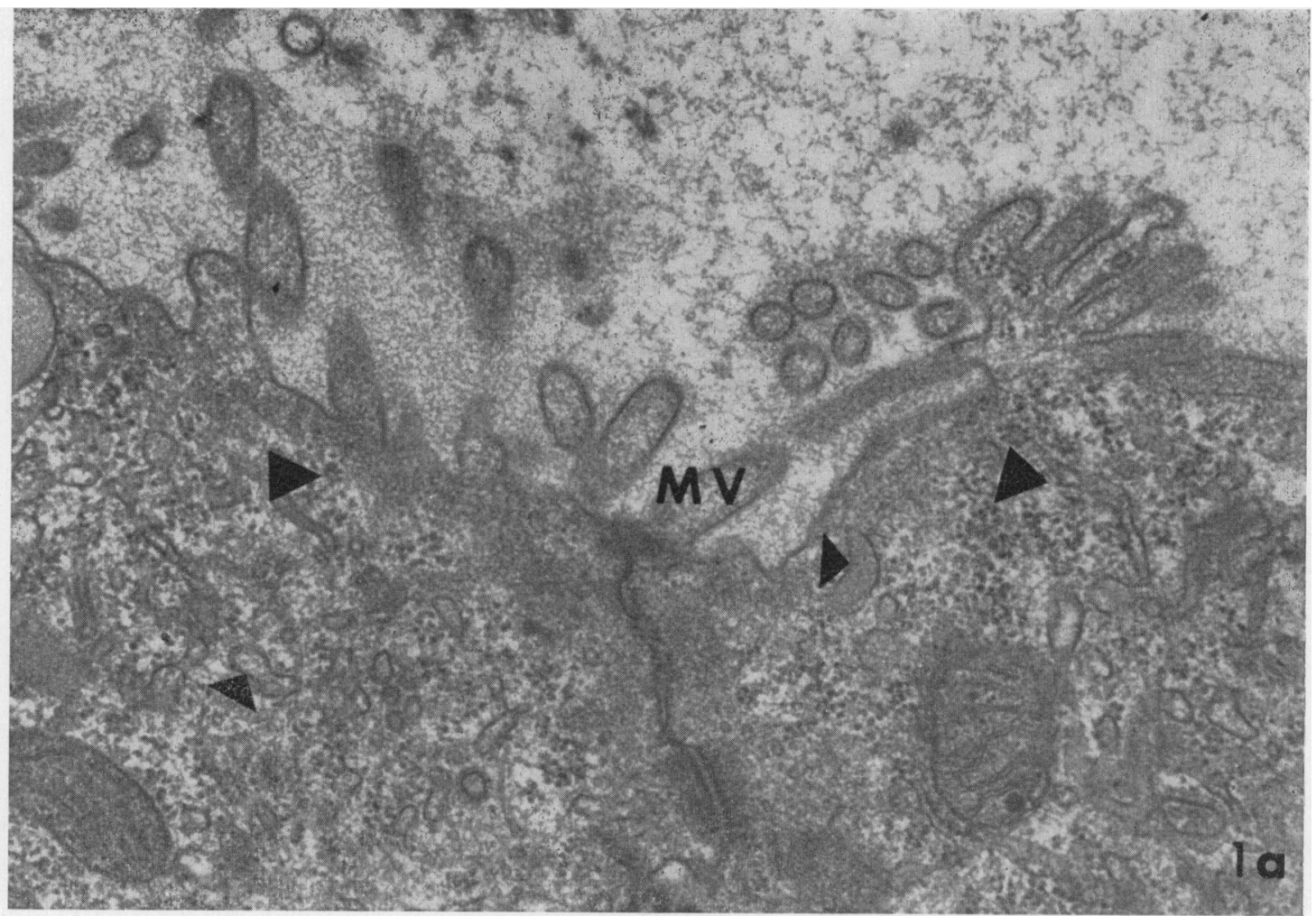

(a)

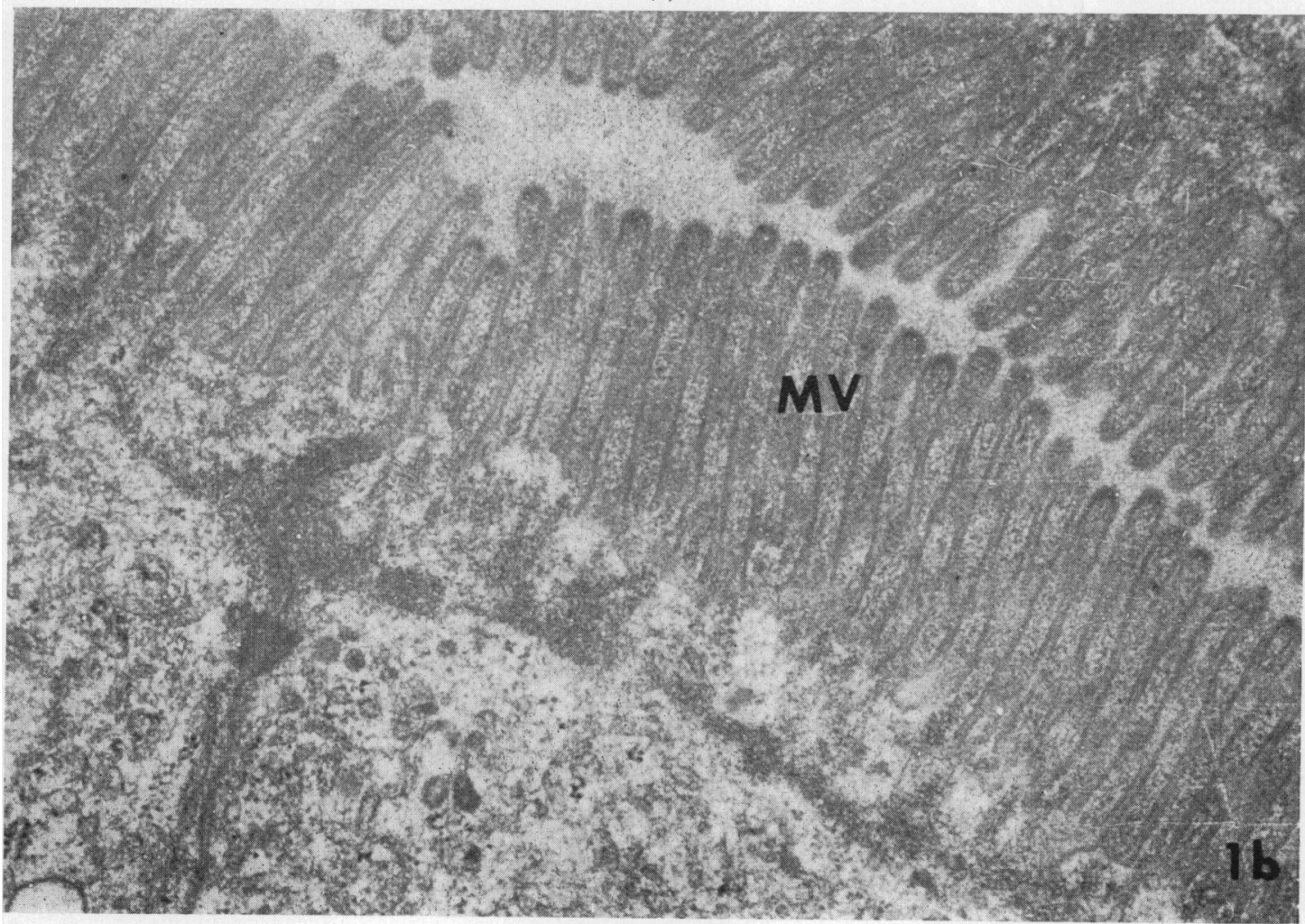




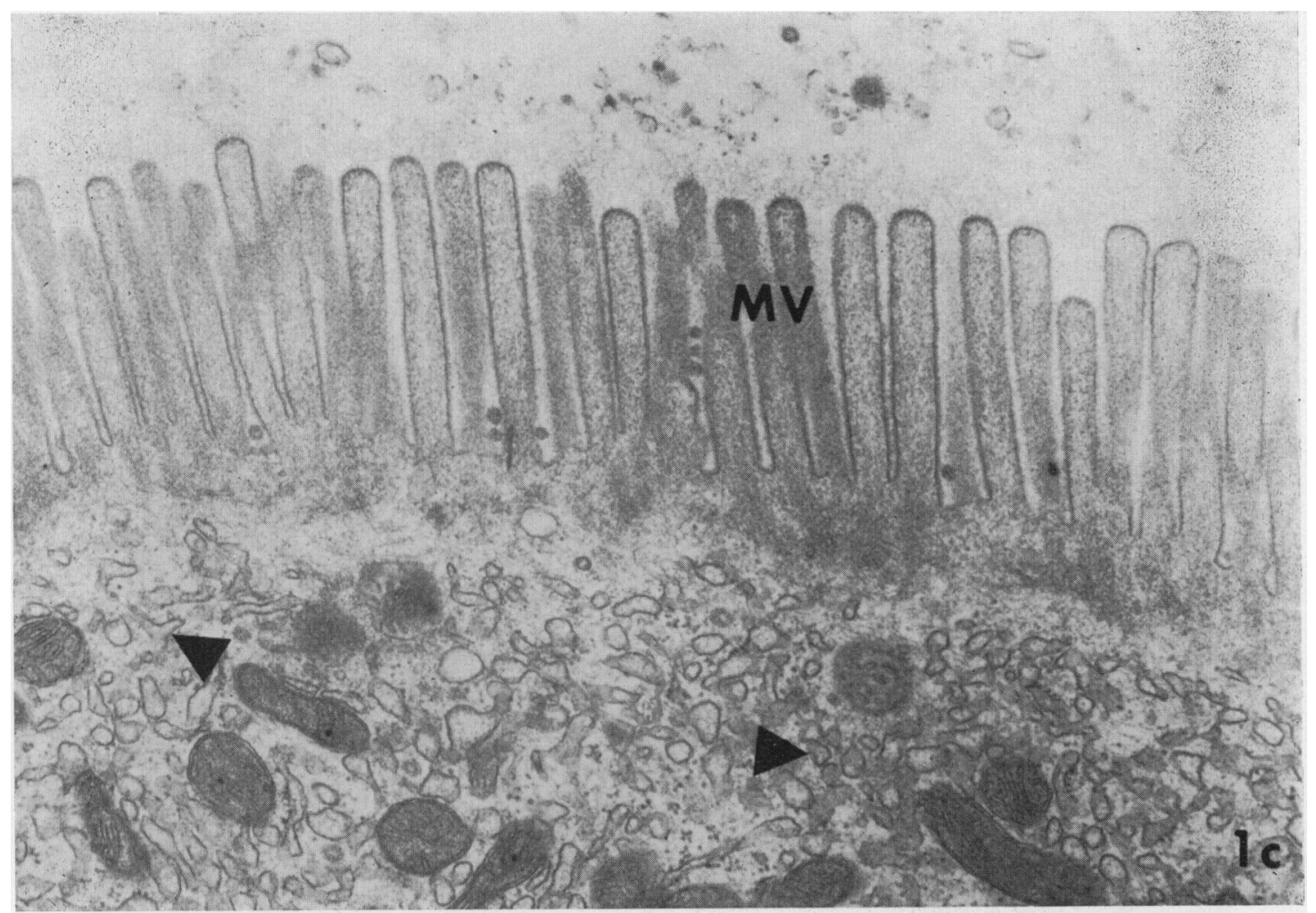

(c)

FIG. 1.-Different appearances of the brush border. Osmium fixed. Magnification $21600 \times$. (a) Case 10. Coeliac patient. The main features are disorganized microvilli $(M V)$, moderately developed smooth endoplasmic reticulum (small arrows), and numerous free ribosomes (large arrows). (b) Case 4. Coeliac patient. Normal brush border in a villus area. $M V$, normal microvilli. (c) Case 20. Child with giardiasis. Normal microvilli $(M V)$ and rich smooth endoplasmic reticulum (large arrows) are the main features.

fibres in some coeliac biopsies. Lateral membranes and intercellular spaces showed a normal profile in all cases.

Lysosomes appeared in clusters and were larger and of unhomogenous material in the coeliac cases. Multivesicular bodies were frequent in all cases. Autophagosomes and residual bodies were seen in some noncoeliac biopsies, but not in the coeliac ones.

Prominent Golgi, occupying large supranuclear areas as shown in Fig. 2 were observed in 24 of the 30 biopsies; 12 of the 14 coeliacs and 12 of the 16 noncoeliacs (Table II). No lipidic particles were seen in relation to the Golgi. Both the canalicular and vesicular components appeared equally developed, and no difference between villus and crypt areas was found.
Numerous free ribosomes and polysomes (Fig. 3a) were found in the epithelium in the villus areas of 17 of the 30 biopsies, 14 of the 17 were associated with a poorly developed smooth endoplasmic reticulum. This was found 10 times in coeliacs and 7 times in noncoeliacs. Rough endoplasmic reticulum was in general well defined, and little difference was observed between villus and crypt areas and coeliac and noncoeliac biopsies.

Smooth endoplasmic reticulum was in general poorly developed in coeliac biopsies, there being a clear predominance of rough endoplasmic reticulum over smooth endoplasmic reticulum in 6 coeliac biopsies. In noncoeliacs well-developed systems of rich smooth endoplasmic reticulum with numerous and dilated membranes was observed in the villus areas of ten biopsies (Fig. 3b). 


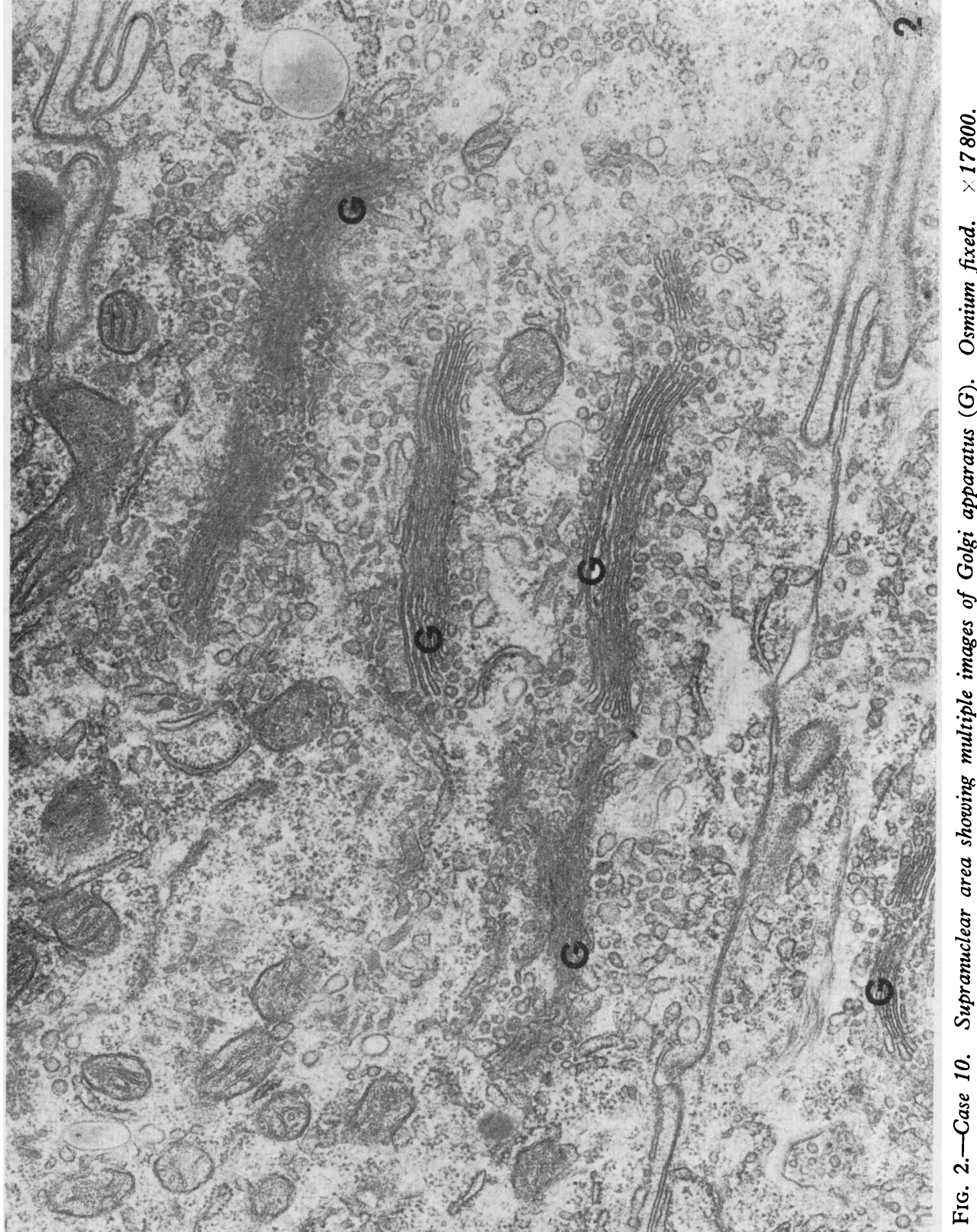

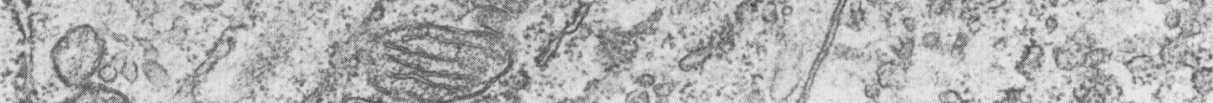



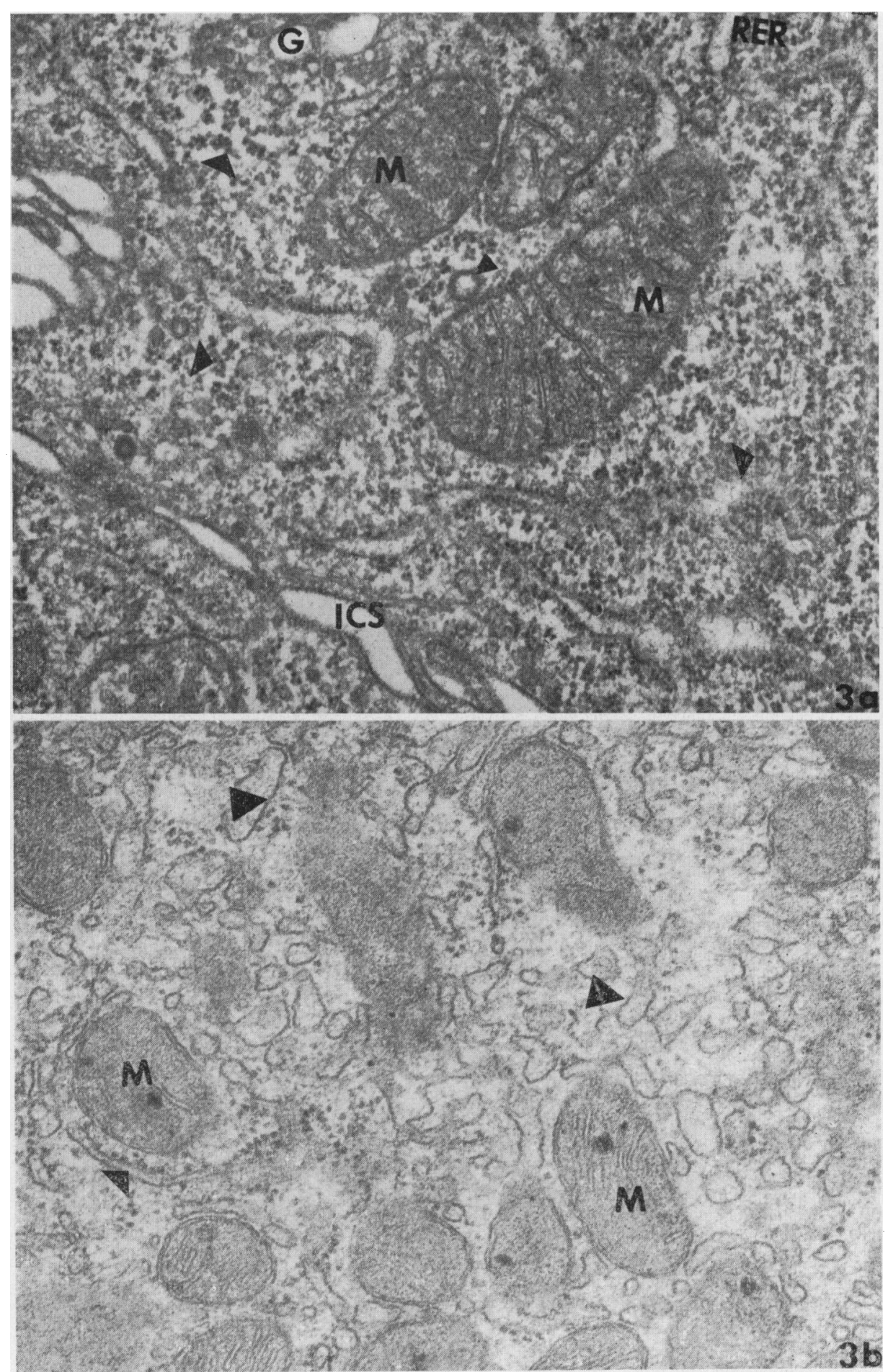

FIG. 3.-Free ribosomes, rough endoplasmic reticulum, and smooth endoplasmic reticulum in villus areas of coeliac and 'noncoeliac' biopsies, respectively. Osmium fixed. $\times 16300 . \quad$ (a) Case 10 coeliac patient. Numerous free ribosomes (small arrows), minimal amounts of smooth endoplasmic reticulum and rough endoplasmic reticulum (RER). Some dilated cistaernae in the Golgi apparatus $(G)$ and some dilatation of the intercellular spaces (ICS) are also seen. $M$, mitochondria. (b) Case 19 noncoeliac patient. Predominance of smooth endoplasmic reticulum (large arrows) over rough endoplasmic reticulum (small arrows), and a few ribosomes in a biopsy from child with steatorrhoea of unknown origin. M, mitochondria. 
In 2 patients with chronic intermittent diarrhoea of no proven cause, loss of the normal relation of mitochondria/rough endoplasmic reticulum was observed (Fig. 4).

A thickened basal lamina (Fig. 5 a, b, c) was found in 16 of the 30 biopsies; 7 times in coeliac patients and 9 times in the noncoeliacs. Only one case (Case 14) showed a thickened basal lamina clearly similar in extent and appearance to that described previously by Shmerling and Shiner (1969) (Fig. 5a). In 15 cases there was a thickened basal lamina in either crypts or villi and in one case, both in crypts and villi. No significant difference was found between the coeliac group and the noncoeliac group with regard to age, or cause of the chronic intermittent diarrhoea, and presence of a thickened basal lamina. Thickening around small capillary vessels (Fig. 5a), as described by Shiner (1970), was found in some coeliacs, but not in the noncoeliac biopsies.

\section{Discussion}

Disorganization of the brush border was characteristic in all 14 coeliac biopsies. However, the presence of extensive areas of normal microvilli in one patient (Case No. 4) is contrary to the accepted concept that in coeliac disease there is a universal lesion at least at light microscope level.

Images of prominent Golgi of normal profile were present in most biopsies. There is some controversy about Golgi complexes in coliac disease. Biempica et al. (1968) found 'very small or only remnants' of Golgi in coeliac patients, while Shiner (1967) has reported 'an increase in number and size' of Golgi complexes under the same circumstances. Our present results agree entirely with this latter description.

An increased number of free ribosomes have been reported by Trier and Rubin (1965) and Biempica et al. (1968) in coeliac patients, and by Wartiovaara

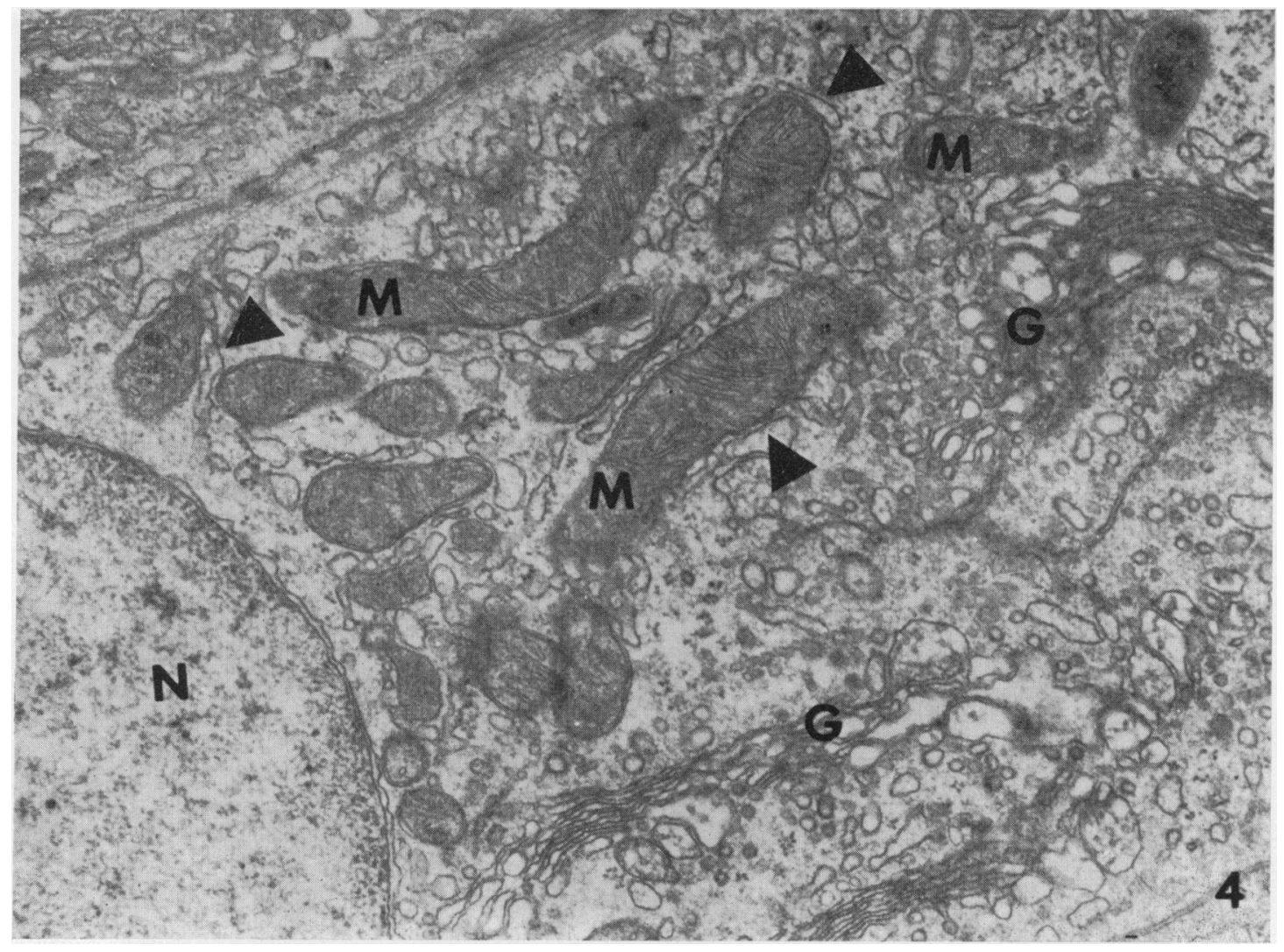

FIG. 4.-Case 24. Supranuclear area showing loss of the normal spatial relation of mitochondria (M) to rough endoplasmic reticulm. $\quad N$, nucleus; $\Delta$, smooth endoplasmic reticulum; $g$, golgi. $\quad \times 6350$. 
and Tarpila (1973) after a certain dose of irradiation in the small intestine of rats. All these changes, together with the changes in smooth and rough endoplasmic reticulum, suggest an abnormal cellular activity, but with our present data we cannot relate them more specifically to any pathological entity.

A thickened basal lamina in 9 of the 16 children who did not have coeliac disease indicates that this is not a primary or essential feature of early child- hood coeliac disease. It may occur in cases of nonspecific small intestinal mucosal lesion.

Only one case (Case 14) was thought to have, during the blind study, the typical appearance of adult coeliac disease. Whether age could influence the production of a thickened basal lamina in a more specific manner, we cannot say, because this study included 30 children consecutively studied and only one case (the above mentioned one) was older than $6 \frac{1}{2}$ years.

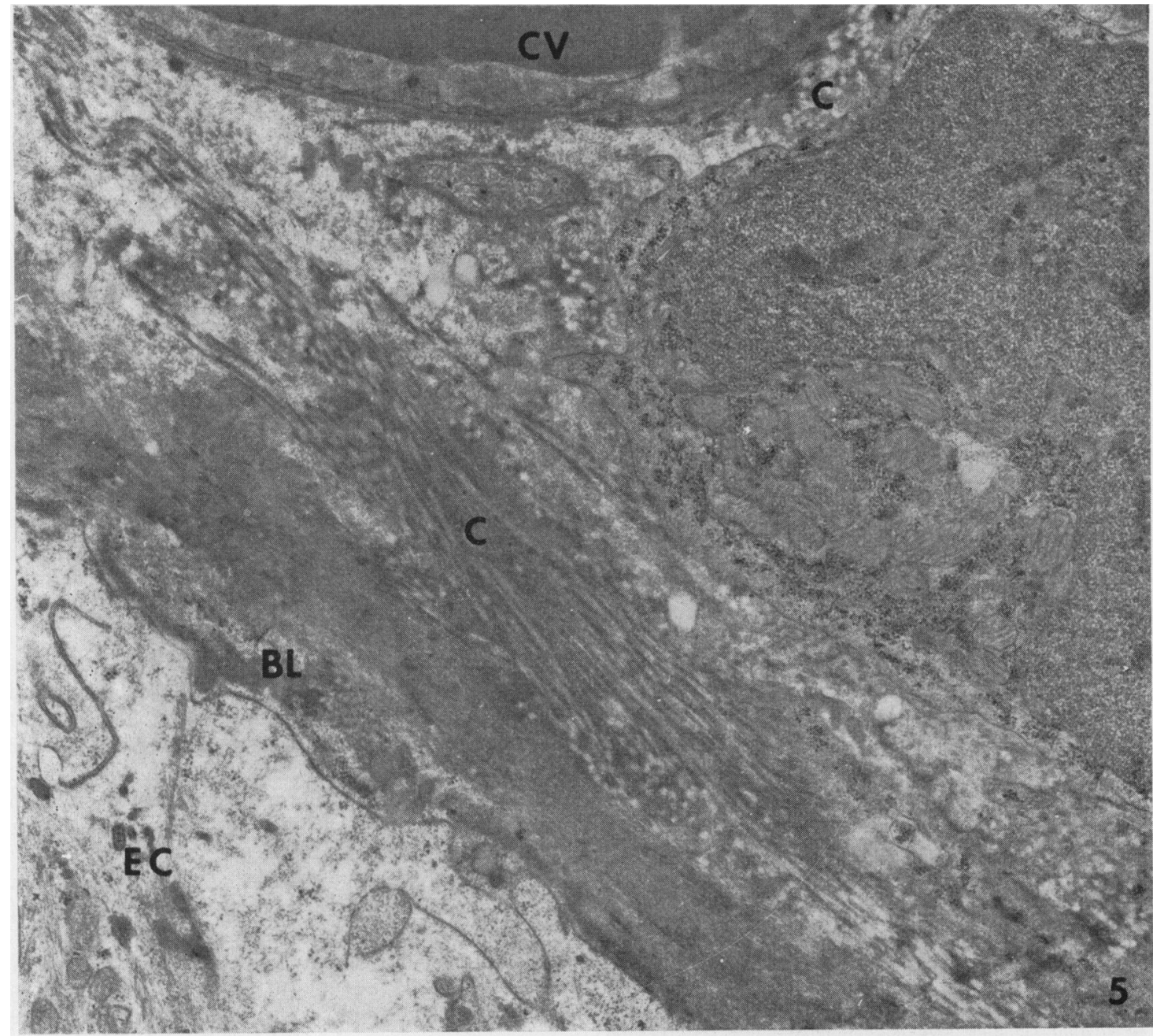

(a)

FIg. 5.-Different appearances of the basal lamina. Osmium fixed. (a) Case 14. Coeliac disease. Thickened basal lamina (BL) with abnormal amounts of collagen $(C)$, and some 'white fibres'. The thickening is also seen around a capillary vessel $(C V)$, which contains a red blood cell. EC, epithelial cell. $\times 13600$. 


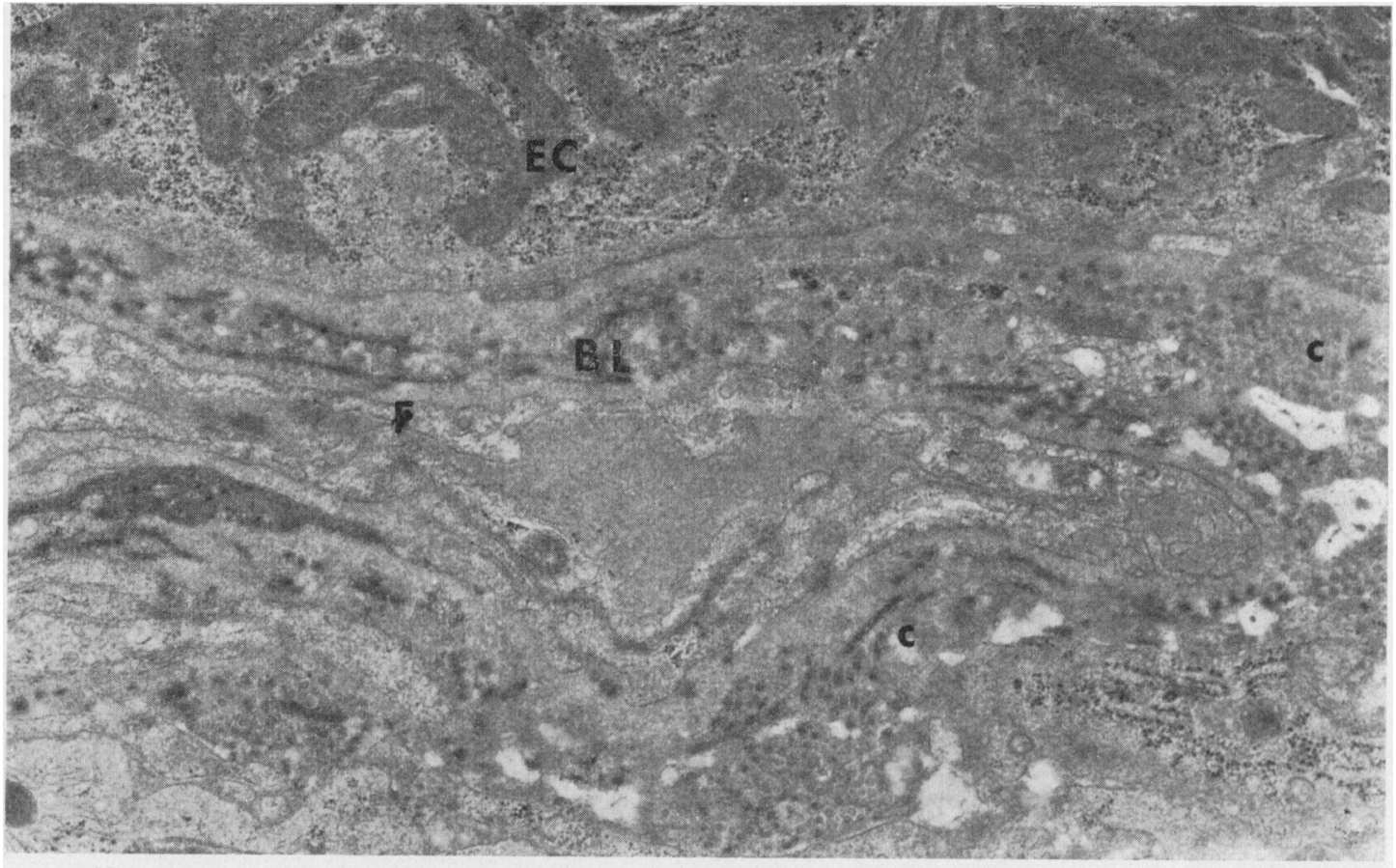

(b)

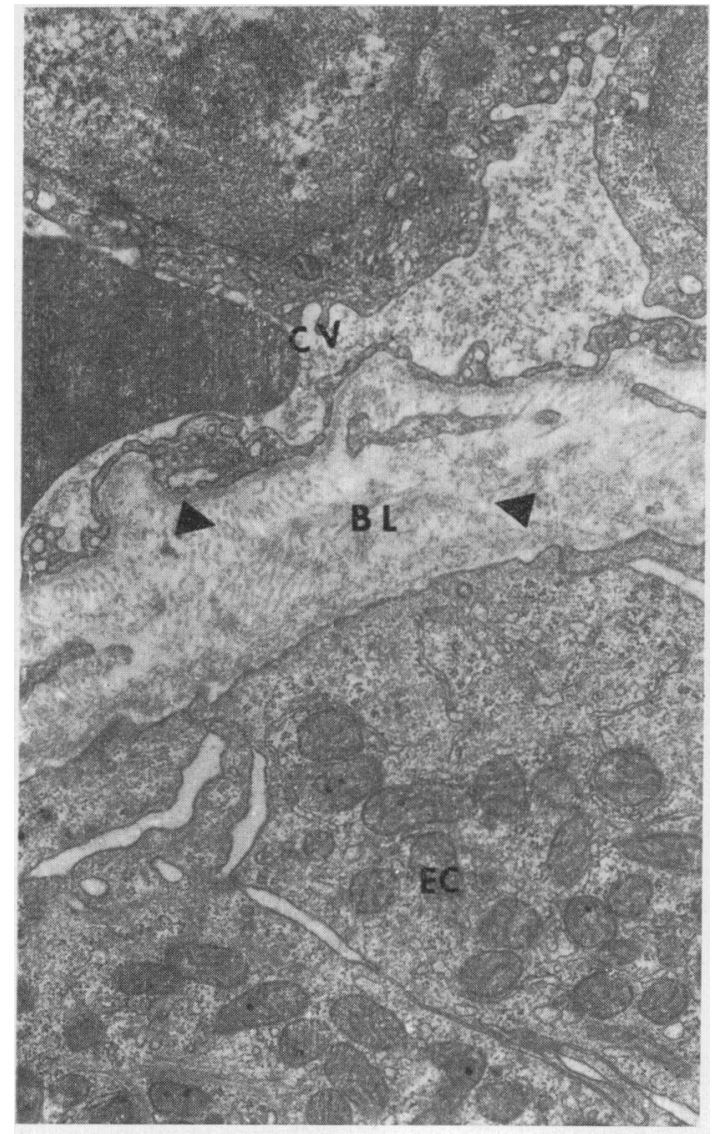

Fig. 5.-(b) Case 23. Patient with cow's milk intolerance. The basal lamina $(B L)$ is thickened with abundant collagen (c). EC, epithelial cell, $F$, fibroblast projection. $\times 13600$. (c) Case 17. Patient with postgastroenteritis syndrome. Moderate amounts of collagen $(\mathbf{\Delta})$ thicken the basal lamina $(B L)$ without major involvement of the capillary vessel $(C V)$ wall. EC, epithelial cell. $\times 13200$.

Kuitunen et al. (1973) presented evidence that infants with cow's milk protein intolerance and malabsorption syndrome during the first months of life present coeliac-like ultrastructural changes in the intestinal epithelium, describing in one child 'accumulation of undulating and whorled collagen fibres' at the basal lamina. This is in agreement with our findings (Fig. 5b).

All the evidence available seems to show that changes of the fine structure of the epithelial cell of the small intestine are nonspecific.

Lindberg and Meeuwisse (1973) have recently reported that 8 out of 40 children diagnosed as having coeliac disease, because they fulfilled the same criteria we used to select our patients, did not reproduce a flat mucosa after 2 years of challenge by being on a gluten-containing diet.

A flat small intestinal mucosa, or a mucosa with severe partial villous atrophy, has been described in 
a number of disorders other than coeliac disease. These include acute gastroenteritis (Ament, 1972), cow's milk protein intolerance (Kuitunen et al., 1973), giardiasis (Ament, 1972), and soy protein intolerance (Ament and Rubin, 1972). While a flat mucosa still most often suggests the diagnosis of coeliac disease, it may be due to other causes.

As mentioned above, the children presented here as coeliacs cannot be diagnosed with certainty until each child has been investigated by gluten challenge to show permanent intolerance to gluten. It is thus possible that the morphological changes shown in this study will prove with time to be in some cases related not to coeliac disease alone but rather to mucosal damage from any cause. If this is the case, it would provide an explanation for the lack of specificity in the ultrastructural changes observed.

We conclude firstly that in small children who have a severely abnormal mucosa, where the diagnosis of coeliac disease is probable, abnormal brush border and lysosomes, increased number of free ribosomes, poorly developed smooth endoplasmic reticulum, large Golgi complexes, and thickened basal lamina are the most frequent findings. However, there is no evidence to support the fact that these morphological changes are specifically related to this disease. Secondly, in small children who present with various clinical conditions (such as cow's milk protein intolerance, postgastroenteritis syndrome, irritable colon syndrome, or chronic intermittent diarrhoea of unknown cause) and in whom the light microscope appearance of the mucosa is normal or shows a mild degree of partial villous atrophy, the same type of electron microscope changes as described above can be observed: the relation between the severity of the changes shown in light microscopy and those observed in electron microscopy is poor.

The authors express their gratitude to Dr. M. Shiner for her comments on the coded electron micrographs. The electron microscope work was performed at the Electron Microscope Unit, The University of Sydney.

\section{REFERENCES}

Ament, M. E. (1972). Malabsorption syndromes in infancy and childhood-Part I. Fournal of Pediatrics, 81, 685.

Ament, M. E., and Rubin, C. E. (1972). Soy protein-another cause of the flat intestinal lesion. Gastroenterology, 62, 227.
Biempica, L., Toccalino, H., and O'Donnell, J. C. (1968). Cytochemical and ultrastructural studies of the intestinal mucosa of children with coeliac disease. American fournal of Pathology, 52, 795.

Brown, A. L. (1962). Microvilli of the human jejunal epithelial cell. Fournal of Cell Biology, 12, 623.

Curran, R. C., and Creamer, B. (1963). Ultrastructural changes in some disorders of the small intestine associated with malabsorption. Fournal of Pathology and Bacteriology, 86, 1.

Hartman, R., Butterworth, C. E., Jr., Hartman, R. E., Crosby, W. H. and Shirai, A. (1960). An electron microscopic investigation. of the jejunal epithelium in sprue. Gastroenterology, 38, 506 .

Hartman, R., Smith, R. B. W., Hartman, R. S., Butterworth,C. E., Jr., and Molesworth, J. M. (1959). The electron microscopy of human intestinal epithelium obtained with the Crosby intestinal biopsy capsule. Fournal of Biophysical and Biochemical Cytology, 5, 171.

Kuitunen, P., Rapola, J., Savilahti, E., and Visakorpi, J. K. (1973). Response of the jejunal mucosa to cows' milk in the malabsorption syndrome with cows' milk intolerance. Acta Paediatrica Scandinavica, 62, 585.

Lindberg, T., and Meeuwisse, G. (1973). Transient coeliac disease-does it exist? Acta Paediatrica Scandinavica, Suppl. 236, 56.

Palay, S. L., and Karlin, L. J. (1959). An electron microscopic study of the intestinal villus. I. The fasting animal. fournal of Biophysical and Biochemical Cytology, 5, 363.

Reynolds, E. S. (1963). The use of lead citrate at high $\mathrm{pH}$ as an electron opaque stain in electron microscopy. fournal of Cell Biology, 17, 208.

Rubin, C. E., Brandborg, L., Phelps, P. C., and Taylor, H. C., Jr. (1960). Studies of coeliac disease. I. The apparent identical and specific nature of the duodenal and proximal jejunal lesion in coeliac disease and idiopathic sprue. Gastroenterology, 38, 28.

Shmerling, D. H., and Shiner, M. (1969). The response of the intestinal mucosa to the intraduodenal instillation of gluten in patients with coeliac disease during remission. Coeliac Disease, Proceedings of an International Conference, p. 64. Ed. by C. C. Booth and R. H. Dowling. Churchill, Livingstone, Edinburgh.

Shiner, M. (1967). Ultrastructure of jejunal surface epithelium in untreated idiopathic steatorrhoea. British Medical Bulletin, 23, 223.

Shiner, M. (1970). Mucosal vascular changes in coeliac disease and in idiopathic steatorrhoea. Micron, 2, 7.

Shiner, M., and Birbeck, M. S. C. (1961). The microvilli of the small intestinal surface epithelium in coeliac disease and in idiopathic steatorrhoea. Gut, 2, 277.

Shiner, M. and Schmerling, D. H. (1970). Pathogenesis of coeliac disease. Gut, 11, 1058.

Trier, J. S. (1963). Studies on small intestinal crypt epithelium. I. The fine structure of the crypt epithelium of the proximal small intestine of fasting humans. Fournal of Cell Biology, 18, 599.

Trier, J. S., and Rubin, C. (1965). Electron microscopy of the small intestine. A review. Gastroenterology, 49, 574.

Trump, B. F., Smuckler, E. A., and Benditt, E. P. (1961). A method for staining epoxy sections for light microscopy. fournal of Ultrastructure Research, 5, 343.

Wartiovaara, J., and Tarpila, S. (1973). Cell contacts and ribosomes in irradiated human intestinal mucosa. Fournal of Ultrastructure Research, 44, 446.

Watson, M. L. (1958). Staining of tissue sections for electron microscopy with heavy metals. fournal of Biophysical and Biochemical Cytology, 4, 475.

Correspondence to Dr. M. Araya, Institute of Child Health, Royal Alexandra Hospital for Children, Camperdown, N.S.W., 2050, Australia. 